Etnolingual Vol 3 No 2

November, 2019, 105-117

\title{
AMBULANS PEMBAWA BATU: KAJIAN LINGUISTIK FORENSIK
}

\author{
Ahmad Hamidi \\ ahmad.hamidi81@ui.ac.id/mr.hamidixxx@gmail.com \\ Departemen Ilmu Linguistik \\ Fakultas Ilmu Pengetahuan Budaya \\ Universitas Indonesia
}

\begin{abstract}
The research was aimed to decribe the utterance about "ambulance carrying stones" through morphosemantics and pragmatics analyses that were shaded by the forensic linguistics paradigm. In this research, qualitative descriptive was applied as the method and case study was designed. The utterance about "ambulance carrying stones" was used as the data, meanwhile the data source was a screenshot of one of influencers' tweet on Twitter and then as known as SP. In this research, the researcher used morphosemantic and speech act theories in order to find the results to achieve the research objectives. The results of the data demonstrated that (1) SP attempted to construct the interpretation of his audience using 'carrier' as the diction related to the ambulance carrying stones, (2) SP's utterance could be concluded that it did not fulfill any of the requirements formulated by Austin (1962) and Searle (1969) regarding the felicity conditions, and (3) the results of the linguistic analysis and the elements in the legal documents demonstrated the constitutionality that those legal documents could ensnare SP.
\end{abstract}

Keywords: forensic linguistics, pragmatics, morphosemantics

\begin{abstract}
Abstrak
Penelitian ini bertujuan untuk mendeskripsikan tuturan mengenai "ambulans pembawa batu" melalui analisis morfosemantik dan pragmatik yang dipayungi oleh paradigma linguistik forensik. Metode yang digunakan dalam penelitian ini adalah deskriptif kualitatif yang desainnya berupa studi kasus. Data dalam penelitian ini berupa tuturan "ambulans pembawa batu", sedangkan sumber datanya adalah hasil tangkapan layar cuitan Twitter salah seorang pemengaruh yang kemudian disebut sebagai SP. Dalam penelitian ini, peneliti menggunakan teori morfosemantik dan tindak tutur dalam rangka menemukan hasil demi mencapai tujuan penelitian yang telah ditetapkan. Hasil penelitian ini menunjukkan bahwa (1) SP berusaha untuk mengonstruksi penafsiran audiensnya menggunakan diksi 'pembawa' terkait dengan kasus ambulans pembawa batu, (2) tuturan SP dapat dikatakan tidak memenuhi satu pun persyaratan yang diformulasikan oleh Austin (1962) dan Searle (1969) tentang kondisi kesahihan, dan (3) hasil analisis secara linguistis dan unsur-unsur dalam peraturan perundang-undangan menunjukkan kesesuaian bahwa peraturan perundang-undangan tersebut dapat menjerat SP.
\end{abstract}

Kata Kunci: linguistik forensik, pragmatik, morfosemantik 


\begin{abstract}
Ahmad Hamidi
PENDAHULUAN

Bentrokan antara massa aksi dengan Brimob yang terjadi pada 25 September lalu menyisakan kegaduhan di tengah masyarakat Indonesia. Kegaduhan tersebut muncul akibat kesimpangsiuran informasi yang beredar di media sosial tentang video rekaman yang memperlihatkan penggeledahan terhadap ambulans berlogo Pemerintah Provinsi (Pemprov) DKI Jakarta yang diduga mendistribusikan batu dan bensin untuk digunakan oleh massa aksi. Sebagian orang menduga bahwa ada pihak-pihak tertentu yang telah menyebarkan berita hoaks dan berusaha untuk mendiskreditkan Pemprov DKI Jakarta.
\end{abstract}

Menariknya, video rekaman tersebut bukanlah berasal dari institusi resmi pemerintahan yang berhak menyebarkan informasi semacam itu. Video tersebut berasal dari akun Twitter salah seorang pemengaruh (influencer) media sosial, yaitu SP. Melalui akunnya, SP mengunggah video rekaman tersebut sekaligus membubuhkan cuitan yang berbunyi "Hasil pantauan malam ini...Ambulans pembawa batu ketangkap pake logo@DKIJakarta”. Sontak video tersebut menjadi viral di berbagai beranda media sosial seumpama jamur yang tumbuh di musim penghujan.
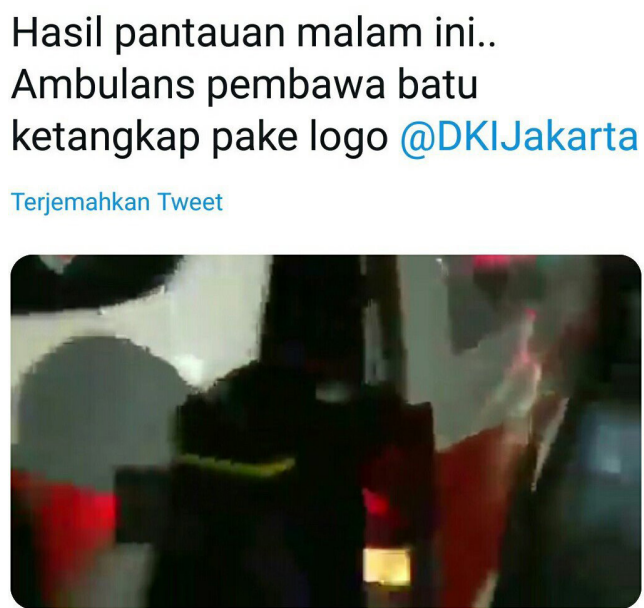

130rb tayangan

1:24 $\cdot 26$ Sep $19 \cdot$ Twitter for Android

\title{
Gambar 1. Tangkapan layar cuitan SP
}

Informasi ini menarik perhatian netizen. Hal itu dapat dibuktikan dengan naiknya tagar \#ManaBatunya sebagai topik populer di Twitter dalam hitungan jam setelah kejadian-yang dapat dimaknai sebagai representasi bentuk ketidakpercayaan dan sanggahan netizen terhadap informasi itu. Di satu sisi, ada pihak-pihak yang menyatakan bahwa informasi dalam cuitan SP itu bukanlah hoaks karena memang benar ditemukan batu di dalam ambulans tersebut. Yang terjadi, menurut pihak-pihak ini, adalah salah penafsiran belaka. Di lain sisi, SP dituding telah menyebarkan informasi yang tidak jelas juntrungan kebenarannya. Sekalipun memang ditemukan sejumlah batu, tidak 
jelas bagaimana kronologinya batu-batu tersebut berada di dalam ambulans itu. Artinya, letak hoaks dalam cuitan SP bukan tentang ada atau tidaknya batu di dalam ambulans, melainkan berkaitan dengan diksi pembawa yang digunakannya.

Kendati menimbulkan kontestasi wacana di tengah masyarakat, berdasarkan cuitan itu, TH yang mewakili Lembaga Swadaya Masyarakat (LSM) Jakmove melaporkan SP ke jalur hukum. Laporan tersebut diterima oleh Sentra Pelayanan Kepolisian Terpadu (SPKT) Markas Kepolisian Daerah Republik Indonesia (Mapolda) Metro Jaya pada Jumat (27/9). Dalam laporannya, TH menyatakan bahwa terlapor telah melakukan penyebaran berita hoaks terkait dengan situasi yang terjadi di tempat aksi massa berlangsung.

Apabila ditelisik secara etimologis, hoaks yang diadaptasi dari kata hoax, bermakna an act intended to trick or dupe, something accepted or established by fraud or fabrication ${ }^{1}$, a humorous or malicious deception ${ }^{2}$, dan a trick or something else that is intended to deceive someone ${ }^{3}$. Sementara itu, berdasarkan Kamus Besar Bahasa Indonesia (KBBI), konsep dari keempat definisi tersebut dirampingkan secara sederhana menjadi berita bohong. Secara jelas dan tegas, dalam konteks ini, hoaks dapat dipahami sebagai nomina yang merujuk kepada segala bentuk informasi yang tidak faktual.

Secara eksplisit, peraturan perundang-undangan Indonesia tidak mengenal terminologi hoaks. Namun demikian, apabila ditinjau berdasarkan isi laporannya, secara kontekstual, ada beberapa peraturan yang dapat menjerat SP, yaitu (1) Pasal 28 Ayat (2) UU 19/2016 tentang Perubahan Atas UU 11/2008 tentang ITE, (2) Pasal 390 KUHP, dan (3) Pasal 14 dan Pasal 15 UU 1/1946. Dengan begitu, dapat dikatakan bahwa tindakan menyebarkan hoaks merupakan salah satu tindakan yang dapat dipidanakan.

Berdasarkan pemaparan yang telah diutarakan sebelumnya, secara substansial, permasalahan yang berusaha untuk ditemukan jawabannya melalui analisis dalam penelitian ini adalah pembuktian secara linguistis terhadap tuturan yang dijadikan sebagai barang bukti perkara pidana dalam kasus penyebaran hoaks tentang ambulans pembawa batu yang dilakukan oleh SP. Penelitian semacam ini dapat dijadikan sebagai bahan referensi bagi pihak-pihak yang berkepentingan guna mendukung proses peradilan, namun bukanlah menjadi satu-satunya legitimasi dalam menentukan ketetapan hukum terhadap subjek penelitian yang semata-mata merupakan wewenang pihak-pihak yang berada dalam wilayah pengadilan. Atas dasar itu, pertanyaanpertanyaan dalam penelitian ini dirumuskan sebagai berikut, yaitu (1) bagaimana analisis morfosemantik diksi pembawa dalam tuturan yang dijadikan sebagai barang bukti perkara pidana dalam kasus penyebaran hoaks tentang ambulans pembawa batu

1 https://www.merriam-webster.com/dictionary/hoax\#h2

2 https://www.lexico.com/en/definition/hoax

3 https://dictionary.cambridge.org/dictionary/english/hoax 


\begin{abstract}
Ahmad Hamidi
yang dilakukan oleh SP?, (2) bagaimana analisis tindak tutur dalam tuturan yang dijadikan sebagai barang bukti perkara pidana dalam kasus penyebaran hoaks tentang ambulans pembawa batu yang dilakukan oleh SP?, dan (3) bagaimana kesesuaian antara hasil analisis secara linguistis terhadap peraturan perundang-undangan yang dapat menjerat SP?
\end{abstract}

\title{
LANDASAN TEORI
}

Dalam bagian ini akan dibahas sejumlah teori yang melandasi penelitian ini, yaitu (1) linguistik forensik, (2) morfosemantik, dan (3) tindak tutur. Ketiganya akan dijelaskan sebagai berikut.

\section{1) Linguistik Forensik}

Terminologi linguistik forensik (forensic linguistics) pertama kali diperkenalkan pada tahun 1968 oleh Jan Svarvik. Kisah ini berawal ketika ia terlibat dalam penyelesaian kasus pembunuhan yang mengundang perhatian dunia akibat kesalahan pengadilan dalam menjatuhkan vonis hukuman mati kepada Timothy John Evans, tersangka pembuhuhan istri dan anak perempuannya di Inggris pada tahun 1950. Berselang 18 tahun kemudian, melalui analisis linguistiknya, Svartvik berhasil membuktikan bahwa Evans, yang ketika itu telah dieksekusi mati, tidak bersalah dalam kasus tersebut. Diketahui kemudian bahwa yang menjadi otak dalam kasus pembunuhan itu adalah tetangga mereka sendiri, yaitu John Reginald Halliday Christie. Kesalahan pengadilan dalam menjatuhkan vonis timbul sebagai akibat dari kesaksian Evans yang cenderung berubah-ubah. Sejak saat itu, linguistik dianggap penting dalam membantu proses penyidikan terkait dengan pemaknaan bahasa yang menjadi bukti hukum.

Menurut Olsson (2008), linguistik forensik adalah kajian mengenai hubungan antara bahasa dengan penegakan, masalah, perselisihan atau proses dalam hukum dan perundang-undangan yang berpotensi melibatkan sejumlah pelanggaran terhadap hukum atau keharusan untuk mendapatkan penyelesaian hukum. Apabila diperinci lagi, linguistik forensik mengkaji mengenai (1) bahasa dari dokumen hukum, (2) bahasa dari polisi dan penegak hukum, (3) wawancara dengan anak-anak dan saksi-saksi yang rentan dalam sistem hukum, (4) interaksi dalam ruang sidang, (5) bukti-bukti linguistik dan kesaksian ahli dalam persidangan, (6) kepengarangan dan plagiarisme, dan (7) fonetik forensik dan identifikasi penutur (Coulthard \& Johnson, 2007: 5). Ditambahkan oleh Gibbons (2007: 12), linguistik forensik juga mengkaji bahasa yang digunakan di penjara, pengembangan penerjemahan bahasa yang digunakan dalam konteks peristiwa hukum, penyediaan bukti forensik linguistik berbasis pada kepakaran, dan penyediaan kepakaran linguistik dalam penyusunan dokumen hukum serta upaya penyederhanaan bahasa hukum.

Objek kajian dalam linguistik forensik dapat berupa bahasa dalam instrumen hukum, proses hukum atau bahasa sebagai barang bukti, baik secara lisan maupun 
tulisan. Artinya, dalam linguistik forensik terdapat irisan antara penerapan teori, teknik, dan metodologi linguistik terhadap teks-teks hukum. Oleh sebab itu, linguistik forensik merupakan bagian dari linguistik terapan (Coulthard \& Johnson, 2007; 2010; Olsson, 2008). Implikasinya, seluruh tataran dalam kajian linguistik, seperti fonetik, fonologi, morfologi, sintaksis, semantik, pragmatik, kajian wacana, sosiolinguistik, dan geolinguistik/dialektologi dapat diterapkan dalam kajian linguistik forensik, apabila kajian tersebut berkaitan dengan bahasa dalam ranah hukum.

\section{2) Morfosemantik}

Morfosemantik terbentuk melalui gabungan antara kata morfo dan semantik. Morfo diambil dari kata morfologi, yaitu cabang ilmu linguistik yang mengidentifikasi satuan-satuan dasar bahasa sebagai satuan gramatikal. Sementara itu, semantik merupakan cabang ilmu linguistik yang meneliti arti atau makna. Berdasarkan definisi masing-masing kata pembentuknya, morfosemantik dapat dimaknai sebagai cabang ilmu linguistik yang mengidentifikasi satuan gramatikal beserta maknanya (El Qorny, 2017: 90). Morfosemantik juga dapat didefinisikan sebagai kajian semantik suatu kata berdasarkan morfem konstituen yang membentuknya (Dorais, 1984: 3; 2010: 137; 2016: 1). Lebih lanjut, proses morfologis tidak hanya menghasilkan bentuk baru, tetapi juga memperoleh makna baru yang disebut makna gramatikal—sebelumnya hanya mengandung makna leksikal. Pemaknaan tersebut dikaji dalam ilmu tentang makna.

\section{3) Tindak Tutur}

Dalam sejarahnya, Austin (1962) merupakan orang yang bertanggung jawab dalam "mereformasi" pemikiran para filsuf pengikut aliran positivisme logis melalui kumpulan tulisannya yang berjudul How to Do Things with Words. Sebelum kemunculan Austin dengan gagasannya tentang tindak tutur, bahasa dipandang sebagai sesuatu yang konstan yang hanya dapat dinilai kebenaran atau ketidakbenarannya. Misalnya, tuturan "Sianu memiliki akun Twitter pribadi” hanya dapat ditentukan benar atau tidak berdasarkan fakta yang ada, yaitu apakah, secara eksistensial, seseorang yang bernama Sianu memiliki akun Twitter atas namadan dikelola oleh-dirinya sendiri. Pendeknya, fakta menentukan kebenaran proposisi yang terkandung dalam tuturan. Sementara itu, Austin menyatakan ketidaksetujuannya terkait pemikiran itu. Baginya, berbahasa merupakan bagian dari bertindak. Manakala seseorang berbahasa, secara simultan orang tersebut juga tengah melakukan tindakan (bertindak), atau sebaliknya, berbahasa merupakan pengejawantahan tindakan tertentu. Terkait hal itu, Austin mendikotomikan bahwa ada tuturan yang bersifat konstantif dan ada tuturan yang bersifat performatif.

Austin membagi tuturan performatif ke dalam tiga bentuk, yaitu (1) tindak lokusi, (2) tindak ilokusi, dan (3) tindak perlokusi. Sebagaimana yang telah 


\begin{abstract}
Ahmad Hamidi
diutarakan sebelumnya, Austin menegaskan bahwa "we generally perform three types of act simultaneously" (Birner, 2013). Ketiganya akan dibahas, yaitu sebagai berikut.

a) Tindak Lokusi

Tindak lokusi merupakan klasifikasi pertama dalam tindak tutur yang diformulasikan oleh Austin. Di bagian ini, tindakan yang dimaksud adalah tindakan membuat tuturan yang bermakna atau dapat juga dimaknai sebagai tindakan mengekspresikan suatu proposisi. Secara eksplisit, Austin (1962: 94) mendefinisikan sebagai "the act of 'saying something' in this normal sense". Dalam praktiknya, segala bentuk semantis suatu pertuturan diasumsikan sebagai bagian dari tindak lokusi. Dengan kata lain, tindak lokusi memandang suatu tuturan sebagai pernyataan secara literal semata dari penuturnya.

b) Tindak Ilokusi

Tindak ilokusi merupakan klasifikasi kedua dalam tindak tutur yang diformulasikan oleh Austin. Dalam bagian ini, tindakan yang dimaksud adalah tindakan tertentu yang diperformasikan melalui tuturan, yang secara eksplisit tidak dinyatakan dalam bentuk semantis tuturannya.

c) Tindak Perlokusi

Tindak perlokusi merupakan klasifikasi ketiga dalam tindak tutur yang diformulasikan oleh Austin. Di bagian ini, tindakan yang dimaksud bukanlah tindakan membuat tuturan yang bermakna dan bermaksud tertentu semata, melainkan, lebih dari itu, yaitu tindakan yang memberikan efek-efek tertentu kepada mitra tutur. Suatu tuturan akan memberikan efek tertentu bagi mitra tutur dan diterjemahkan sesuai dengan daya ilokusi yang diterima oleh mitra tutur.

Menurut Austin, tuturan performatif tidak serta merta dapat dinilai berdasarkan kebenaran atau ketidakbenaran proposisinya. Yang dinilai dalam tuturan performatif adalah sahih atau tidak sahih-Austin membahasakannya sebagai happy atau unhappy-tuturan tersebut dalam merepresentasikan tindakan yang dilakukan oleh penutur. Untuk mengujinya, Austin memformulasikan ancangan yang disebutnya sebagai felicity conditions-yang secara harfiah dapat diterjemahkan sebagai kondisi kesahihan atau, secara konseptual dapat dimaknai sebagai, syarat kesahihan-yang berisi tiga persyaratan. Agar tuturan dapat bernilai sahih, penutur mesti memenuhi persyaratan tersebut. Ketiga persyaratan yang dimaksud oleh Austin, yaitu (1) harus ada prosedur konvensional yang berefek konvensional (keadaan dan orang harus sesuai seperti yang ditentukan dalam prosedur), (2) prosedur mesti dijalankan secara benar dan sepenuhnya, dan (3) orang-orang yang terlibat dalam prosedur mesti memiliki pemikiran, perasaan, dan niat sesuai dengan yang ditentukan dalam prosedur. Dalam perkembangannya, kondisi kesahihan versi Austin ini rumuskan kembali oleh Searle (1962).
\end{abstract}




\section{METODOLOGI PENELITIAN}

Penelitian ini merupakan penelitian yang dipayungi oleh paradigma linguistik forensik. Ancangan kualitatif dengan pendekatan morfosemantis dan pragmatis digunakan untuk menentukan apakah tuturan yang menjadi objek studi kasus dalam penelitian dapat dikatakan memenuhi atau tidak memenuhi unsur-unsur tindak pidana yang diatur dalam peraturan perundang-undangan. Ada sejumlah alasan yang dapat dijadikan sebagai justifikasi atas pemilihan ancangan dalam penelitian ini, yaitu (1) penelitian ini berusaha untuk mengidentifikasi dan mendeskripsikan fenomena penggunaan bahasa yang berdampak hukum menggunakan paradigma yang ilmiah, (2) penelitian ini disajikan secara deskriptif dan melibatkan pendekatan interpretatif terhadap data yang bersifat alamiah—atau berasal dari kondisi yang alami, dan (3) penelitian ini tidak dilakukan untuk menemukan hasil statistis yang cenderung bersifat kualitatif (lihat Strauss \& Corbin, 1990; Silverman, 2000; Cresswell, 2009).

Sumber data dalam penelitian ini adalah hasil tangkapan layar (screenshot) cuitan salah seorang pemengaruh yang dipublikasikan melalui akun Twitter pribadinya. Sementara itu, yang menjadi data dalam penelitian ini adalah tuturan yang dicuitkan, yaitu "Hasil pantauan malam ini...Ambulans pembawa batu ketangkap pake logo @DKIJakarta", yang diduga sebagai tindak pidana. Sehubungan dengan kode etik pemanfaatan data dalam proses analisis yang digarap melalui penelitian ini, dengan mempertimbangkan konsekuensi yang mesti dihadapi, peneliti mempseudonimkan nama dan nama pengguna (username) Twitter yang merupakan identitas pribadi subjek penelitian. Oleh karena itu, dalam penelitian ini, peneliti menggunakan kode "SP" untuk merujuk subjek penelitian.

Sebagai hasil dari proses kerja ilmiah, perlu ditegaskan, luaran dari penelitian ini sama sekali tidak bertujuan untuk menentukan apakah subjek dalam penelitian ini pantas atau tidak pantas dijerat pasal tindak pidana tertentu. Penelitian ini dapat dilihat sebagai referensi keterangan melalui kacamata linguistis, apabila laporan diterima dan ditindaklanjuti oleh penyidik Direktorat Reserse Kriminal Khusus (Ditreskrimsus) Polda Metro Jaya, yang disajikan berdasarkan paradigma dan metodologi yang lazim digunakan dalam penelitian-penelitian linguistik. Artinya, penelitian semacam ini dapat dijadikan sebagai bahan referensi bagi pihak-pihak yang berkepentingan guna mendukung proses peradilan, namun bukanlah menjadi satu-satunya legitimasi dalam menentukan ketetapan hukum terhadap subjek penelitian yang semata-mata merupakan wewenang pihak-pihak yang berada dalam wilayah pengadilan.

\section{HASIL DAN PEMBAHASAN}

Hasil dan pembahasan penelitian ini dibagi atas tiga segmen, yaitu (1) analisis morfosemantis, (2) analisis tindak tutur, dan (3) kesesuaian hasil analisis dengan peraturan perundang-undangan. Ketiganya akan disajikan sebagai berikut. 


\section{1) Morfosemantis}

Untuk sampai pada tahap menemukan makna literal atau makna denotatif berdasarkan apa yang telah dicuitkan oleh SP melalui akun Twitter-nya, tindakan yang perlu dilakukan adalah memperhatikan secara cermat dan bebas konteks makna atau konsep konvensional yang digunakan oleh SP. Melalui cuitan yang dipublikasikannya itu, SP berusaha untuk mengonstruksi penafsiran dengan menggunakan diksi pembawa. Apabila ditinjau secara morfosemantis, dengan bersandar pada definisi yang termaktub dalam KBBI, pembawa merupakan kata yang dibentuk oleh dua morfem, yaitu pem- sebagai morfem terikat dan bawa sebagai morfem bebas.

Pem- di dalam KBBI, yang merupakan alomorf dari pe-, ditandai sebagai prefiks pembentuk nomina yang mengandung sejumlah makna, yaitu (1) orang yang melakukan, (2) orang yang berprofesi sebagai, (3) orang yang memiliki sifat, dan (4) alat yang dipakai untuk. Sementara itu, bawa ditandai sebagai verba yang bermakna 'angkat ke tempat lain'. Konsekuensinya, kedua morfem tersebut, setelah membentuk kata pembawa, dapat dimaknai sebagai 'orang atau pihak yang membawa sesuatu, dan tindakan membawa tersebut dilakukan secara sengaja dan dengan kesadaran penuh'. Dalam konteks ini, SP memosisikan ambulans sebagai subjek atau pelaku atas tindakan membawa-dalam hal ini, batu.

Pihak kepolisian melalui Kabid Humas Polda Metro Jaya, Kombes Argo Yuwono, mengatakan bahwa memang benar ada lima ambulans berlogo Pemprov DKI ditahan polisi pada Kamis (26/9) pukul 02.14 WIB di dekat Gardu Tol Pejompongan Jalan Gatot Subroto karena di dalamnya ditemukan sejumlah batu dan bensin ${ }^{4}$. Perihal kejadian ini ditegaskan pula oleh pihak kepolisian melalui akun resmi Twitter@TMCPoldaMetro yang mengirimkan cuitan pada pukul 02.14 WIB. Namun demikian, setelah melakukan investigasi, pihak kepolisian mengklarifikasi bahwa ambulans tersebut bukanlah subjek atau pelaku yang membawa batu-batu secara sengaja dari suatu tempat ke tempat kejadian perkara, melainkan batu-batu tersebut merupakan batu yang disembunyikan di dalam ambulans oleh sejumlah massa aksi. Artinya, massa aksi memanfaatkan keberadaan ambulans di tempat itu untuk menyembunyikan batu-batu. Dalam konteks ini, yang menjadi pelaku pembawa batu-batu adalah massa aksi.

Dengan memperhatikan kronologi peristiwanya, dapat diketahui bahwa cuitan yang dikirimkan oleh SP mendahului cuitan yang dikirimkan oleh instansi resmi yang bertanggung jawab sekaligus memiliki wewenang secara institusional dalam mengabarkan informasi tentang pengamanan mobil ambulans pembawa batu. SP mengirimkan cuitan pada pukul 01.24 WIB. Sementara itu, pihak kepolisian

4 Dllansir dari https://megapolitan.kompas.com/read/2019/09/26/07071681/ polisi-5-ambulans-pemprov-dki-angkut-batu-dan-bensin-saat-rusuh?page=all dan diakses pada 11/11/19. 
mengirimkan cuitan pada pukul 02.14 WIB. Ada selisih sekitar 50 menit antara cuitan yang dikirimkan SP dengan cuitan yang dikirimkan oleh Polda Metro Jaya. Implikasinya, SP melalui akun Twitter-nya, termasuk pihak pertama yang menyebarkan informasi ambulans pembawa batu. Lantas pertanyaan yang muncul, apakah SP, dalam posisinya sebagai masyarakat sipil dan bukan bagian dari institusi kepolisian, layak untuk menyebarluaskan informasi yang sifatnya eksklusif dalam ranah kerja yang secara otoritas dinaungi pihak kepolisian? Untuk menguji hal ini, pendekatan yang perlu dilakukan adalah menggunakan teori tindak tutur.

2) Tindak Tutur

Secara konstantif, tuturan "Hasil pantauan malam ini...Ambulans pembawa batu ketangkap pake logo @DKIJakarta" hanya dapat ditentukan benar atau tidak berdasarkan fakta yang ada, yaitu (1) apakah secara eksistensial, ada batu di dalam ambulans dan (2) apakah secara faktual, petugas ambulans itu memang sengaja dengan kesadaran penuh membawa batu. Secara performatif, tuturan tersebut merupakan representasi dari tindakan SP yang menginformasikan kepada mitra tuturnya terkait hasil pemantauan (yang secara literal tidak jelas berdasarkan pemantauan siapa) bahwa ada ambulans berlogo Pemprov DKI Jakarta yang bertindak sebagai subjek yang membawa batu. Dalam konsepsi pragmatis Searle (1969), tuturan tersebut dikategorikan sebagai tuturan yang berdaya ilokusi representatif (asertif).

Berdasarkan kondisi kesahihan dalam tuturan itu, dengan memperhitungkan segala identitas sosial yang melekat dalam dirinya, syarat pertama terkait dengan konvensionalitas prosedur (preparatory conditions) pertuturan tidak dipenuhi oleh SP. Kondisi persiapan mengatur kesesuaian prosedur secara konvensional yang meliputi peserta tutur, konteks waktu dan tempat, dan konteks situasi. Dalam hal ini, posisinya sebagai peserta tutur dan konteks situasi tidak dipenuhi oleh SP. Secara konvensional, orang atau pihak yang memiliki wewenang untuk mengabarkan atau menginformasikan mengenai pengamanan ambulans yang berisi batu, tentu, adalah kepolisian, sehingga sangat tidak sahih apabila SP mendahului pekerjaan yang seharusnya menjadi tanggung jawab kepolisian. Terkait konteks situasi, tuturan SP tersebut merupakan informasi yang penting, bersifat eksklusif, dan berdampak luas terhadap kondisi psikologis masyarakat Indonesia, utamanya masyarakat DKI Jakarta. Oleh sebab itu, informasi semacam itu sudah semestinya dikeluarkan oleh orang yang secara sungguh-sungguh dapat mempertanggungjawabkan kebenarannya dan SP tidak memiliki kuasa atau atribut sosial untuk mempertanggungjawabkan apa yang telah dituturkannya.

Syarat kedua fokus kepada kebenaran dan keutuhan prosedur (essential conditions) yang meliputi proses atau tahap dalam mencapai tindakan dalam tuturan. Agar tuturannya dapat dinilai sahih, ada beberapa hal yang mesti dibuktikan oleh SP kepada para audiensnya demi melegitimasi kebenaran yang tersirat dalam 


\begin{abstract}
Ahmad Hamidi
\end{abstract}
tuturannya. Pertama, siapakah dan bagaimanakah identitas sosial orang yang menjadi informan SP terkait ambulans pembawa batu? Apakah warga setempat, polisi, atau pendengung media sosial (social media buzzer) belaka? Kedua, apakah di dalam ambulans tersebut, secara eksistensial, memang benar ditemukan batu? Ketiga, apakah benar batu-batu tersebut dibawa (dengan sengaja) oleh ambulans ke tempat kejadian perkara? Sepanjang fakta yang diberikan SP dapat menjawab ketiga pertanyaan itu, maka SP dapat dikatakan telah memenuhi persyaratan kedua. Akan tetapi, faktanya, sekalipun mengatakan mendapat video tersebut dari suatu sumber ${ }^{5}$, tidak ada informasi verifikatif yang diberikan oleh SP dalam rangka menjawab secara tegas ketiga pertanyaan itu. Oleh karena itu, tuturan SP tersebut, sejauh ini, dapat dikatakan tidak sahih secara esensial.

Syarat ketiga fokus pada ketulusan (sincerity conditions) penutur terhadap tindakan yang direpresentasikan melalui tuturannya. Yang perlu diperhatikan berdasarkan syarat ini, apakah niat SP dalam menyampaikan informasi terkait batu di dalam ambulans kongruen dengan tindakan yang menyertai tuturannya. Dalam tuturan tersebut, entah sengaja atau tidak, SP menyebut (mentioning) akun resmi Pemprov DKI Jakarta. Dengan begitu, selain sekadar menyampaikan informasi, diduga ada niat lain yang melatarbelakangi tindakan SP terkait kejadian tersebut, misalnya, meminta konfirmasi atau klarifikasi dari pihak Pemprov DKI Jakarta. Akan tetapi, berdasarkan keterangan yang diberikan oleh pihak kepolisian, ambulans yang berlogo Pemprov DKI Jakarta bukanlah satu-satunya ambulans yang diamankan, melainkan, dari lima ambulans, ada empat ambulans lain yang berasal dari instansi Palang Merah Indonesia (PMI) ${ }^{6}$. Pertanyaan yang muncul berdasarkan fakta ini, mengapa SP tidak turut menyebut akun resmi PMI (@ palangmerah) dalam cuitannya setara dengan penyebutan akun resmi Pemprov DKI Jakarta?

Sebagai seorang pemengaruh, SP masyhur sebagai orang yang memiliki kecenderungan politik yang cukup ekstrem kepada pihak-pihak tertentu. Hal itu dapat dibuktikan melalui berbagai tulisannya yang tersebar secara luas dan mudah diakses di media sosial. Tidak jarang, tulisan-tulisannya, sedikit atau banyak, bersifat menyerang pihak-pihak yang secara politis berada di seberangnya. Oleh karena itu, dengan merujuk kepada identitas sosialnya, tuturan SP tentang ambulans pembawa batu dapat dikatakan mengandung niat khusus untuk mendiskreditkan pihak tertentu, dalam konteks ini, yaitu Pemprov DKI Jakarta. Implikasinya, ketulusan SP dalam cuitannya itu tidak dapat dikatakan sebagai menyampaikan

5 Dilansir dari https://www.cnnindonesia.com/nasional/20190927094117-20-434533/denny-siregar-jawab-soal-cuitan-ambulans-batudului-polisi dan diakses pada 11/11/19.

6 Dilansir dari https://megapolitan.kompas.com/read/2019/09/26/11175781/ anies-hanya-1-ambulans-milik-pemprov-dki-yang-ditahan-polisi?page=all dan diakses pada 11/11/19. 
informasi tentang suatu kondisi semata, tetapi ketulusan yang ditunjukkan juga untuk mendiskreditkan pihak Pemprov DKI Jakarta melalui konstruksi informasi yang disampaikannya.

\section{3) Kesesuaian Hasil Analisis dengan Peraturan Perundang-undangan}

Hasil analisis secara morfosemantis menunjukkan bahwa diksi pembawa bermakna 'orang yang membawa'. Dalam tindakan membawa, ada syarat yang mesti dipenuhi agar kata ini bermakna sebagaimana mestinya, yaitu 'kesengajaan' dan kesadaran' sebagai kontradiksi terhadap kata terbawa yang justru mengabaikan 'kesengajaan' dan 'kesadaran' subjek pelaku. Dengan menggunakan diksi pembawa, SP berusaha untuk mengonstruksi penafsiran audiensnya bahwa ambulans (sebagai personifikasi atas petugas ambulans, Dinkes, dan Pemprov DKI Jakarta) membawa batu-batu, yang dalam logika konvensional, dibawa secara sengaja dari satu tempat ke tempat kejadian perkara. Terlepas dari ada atau tidaknya niat SP menyebarkan informasi hoaks dengan menggunakan diksi pembawa ini, namun kenyataannya informasi tersebut memang tidak benar secara faktual.

Setelah mengkaji konteks pertuturannya menggunakan teori tindak tutur, tuturan SP dapat dikatakan tidak memenuhi satu pun persyaratan yang diformulasikan oleh Austin (1962) dan Searle (1969) tentang kondisi kesahihan. Dengan kata lain, SP dapat dikatakan tidak layak untuk menyampaikan sekaligus menyebarluaskan informasi semacam itu, yang pada hakikatnya secara institusional merupakan wewenang pihak kepolisian. Implikasinya, apabila ada pihak-pihak yang tidak menerima dan menyangsikan pernyataannya, bahkan sampai-sampai memidanakannya, hal ini merupakan konsekuensi yang mesti diterima oleh SP sebagai sebuah kenyataan.

Dengan memperhatikan proposisi-proposisi yang termaktub dalam perundangundangan, misalnya, Pasal 28 Ayat (2) UU 19/2016 tentang Perubahan Atas UU 11/2008 tentang ITE yang berbunyi "Setiap Orang dengan sengaja, dan tanpa hak menyebarkan informasi yang ditujukan untuk menimbulkan rasa kebencian atau permusuhan individu dan/atau kelompok masyarakat", informasi yang disebarkan oleh SP sudah dapat dikatakan memenuhi unsur dalam proposisi tersebut, sehingga dapat dikenakan sanksi yang diatur dalam Pasal 45A Ayat (1) UU 19/2016, yaitu “...dipidana dengan pidana penjara paling lama 6 (enam) tahun dan/atau denda paling banyak Rp 1 miliar". Terlepas apakah sengaja atau tidak, tetapi berdasarkan analisis tindak tutur, SP termasuk orang yang "tanpa hak" dalam menyebarkan informasi tersebut melalui media elektronik.

Pasal 15 UU 1/1946 secara tegas juga dapat menjerat SP. Pasal tersebut mengatur bahwa

"Barangsiapa menyiarkan kabar yang tidak pasti atau kabar yang berkelebihan atau yang tidak lengkap, sedangkan ia mengerti setidaktidaknya patut dapat menduga bahwa kabar demikian akan atau sudah dapat 
menerbitkan keonaran di kalangan rakyat, dihukum dengan hukuman penjara setinggi-tingginya dua tahun".

Dengan mengikuti logika dalam pasal ini, SP semestinya telah menyadari sebelumnya bahwa informasi yang disebarkannya itu dapat menimbulkan berbagai interpretasi di tengah masyarakat, terlebih karena identitas sosialnya yang tidak mendukung tindakannya untuk dapat dipercaya sebagai sumber informasi.

\section{KESIMPULAN}

Berdasarkan hasil penelitian dan pembahasan tentang pembuktian secara linguistis terhadap tuturan yang dijadikan sebagai barang bukti perkara pidana dalam kasus penyebaran hoaks tentang ambulans pembawa batu yang dilakukan oleh SP, diperoleh simpulan sebagai berikut.

Pertama, berdasarkan hasil analisis morfosemantik diksi pembawa, ditemukan bahwa SP berusaha untuk mengonstruksi penafsiran audiensnya bahwa ambulans membawa batu-batu. Konstruksi seperti ini dalam logika konvensional bermakna bahwa batu-batu tersebut secara sengaja dibawa dari satu tempat ke tempat kejadian perkara. Terlepas dari ada atau tidaknya niat SP menyebarkan informasi hoaks dengan menggunakan diksi pembawa ini, namun kenyataannya informasi tersebut memang tidak benar secara faktual.

Kedua, berdasarkan hasil analisis tindak tutur, ditemukan bahwa tuturan SP dapat dikatakan tidak memenuhi satu pun persyaratan yang diformulasikan oleh Austin (1962) dan Searle (1969) tentang kondisi kesahihan. Dengan kata lain, SP dapat dikatakan tidak layak untuk menyampaikan sekaligus menyebarluaskan informasi semacam itu, yang pada hakikatnya secara institusional merupakan wewenang pihak kepolisian.

Ketiga, hasil analisis secara linguistis dan unsur-unsur dalam peraturan perundangundangan menunjukkan kesesuaian, sehingga, apabila laporan diterima dan ditindaklanjuti oleh penyidik Ditreskrimsus Polda Metro Jaya, peraturan perundangundangan tersebut dapat menjerat SP.

\section{DAFTAR PUSTAKA}

Austin, J. (1962). How to do things with words. Cambridge: Harvard University Press. Bachari, A.D. (2017). Bahasa dan pidana. Bandung: Penerbit Prodi Linguistik SPs Universitas Pendidikan Indonesia.

Birner, B.J. (2013). Introduction to pragmatics. Sussex: Willey-Blackwell Publishing. Coulthard, M. \& Alison Johnson. (2010). The routledge handbook of forensic linguistics. USA: Milton Park.

Cresswell, J.W. (2009). Research design: qualitative, quantitative, and mixed methods approaches. New York: Sage Publications.

Dorais, L.J. (1984). Humiliation et harmonie. L' expression du droit coutumier chez 
les Inuit du Labrador. Recherches amérindiennes au Québec 14.4: 3-8.

Dorais, L.J. (2010). The language of the Inuit. Syntax, semantics, and society in the Artic. Montreal-Kingston: McGill-Queen's University Press.

Dorais, L.J. (2016). Morphosemantics and their limits: three Inuit examples. Amerindia 38: 47-86.

El Qorny, A. (2016). Produktivitas fi'i dalam perubahan dan pemaknaan. Lisanan Arabiya 1.2: 77-115.

Gibbons, J. (2007). Forensic linguistics: an introduction to language in the justice system. Oxford: Blackwell Publishing.

Grundy, P. (2008). Doing pragmatics. London: Hodder Arnorld Publication.

Huang, Y. (2007). Pragmatics. New York: Oxford University Press.

McMenamin, G. (2002). Forensic linguistics: advances in forensic stylistics. Florida: CRC Press.

Olsson, J. (2008). Forensic linguistics. London: Continuum International Publishing Company.

Silverman, D. (2000). Doing qualitative research: a practical handbook. London: Sage Publications.

Soesilo, R. (1991). Kitab undang-undang hukum pidana (kuhp) serta komentarkomentarnya lengkap pasal demi pasal. Bogor: Politeia.

Strauss, A \& Juliet Corbin. (1990). Basics of qualitative research: grounded theory procedures and techniques. London: Sage Publications. 